Article

\title{
Denitrification-Potential Evaluation and Nitrate-Removal-Pathway Analysis of Aerobic Denitrifier Strain Marinobacter hydrocarbonoclasticus RAD-2
}

\author{
Dedong Kong ${ }^{1}$, Wenbing Li $^{2}$, Yale Deng ${ }^{3}\left(\mathbb{D}\right.$, Yunjie Ruan ${ }^{4,5}, *$, Guangsuo Chen ${ }^{2}$, Jianhai Yu ${ }^{2}$ \\ and Fucheng Lin ${ }^{1}$ \\ 1 Agricultural Experiment Station, Zhejiang University, Hangzhou 310058, China; ntzx@zju.edu.cn (D.K.); \\ fuchenglin@zju.edu.cn (F.L.) \\ 2 Key Laboratory of Hangzhou City for Ecosystem Protection and Restoration, College of Life and \\ Environmental Sciences, Hangzhou Normal University, Hangzhou 310036, China; lwb@hznu.edu.cn (W.L.); \\ chenguangsuo@163.com (G.C.); yujianhai723@163.com (J.Y.) \\ 3 Aquaculture and Fisheries Group, Department of Animal Sciences, Wageningen University, \\ 6708 WD Wageningen, The Netherlands; yale.deng@wur.nl \\ 4 Institute of Agricultural Bio-Environmental Engineering, College of Bio-systems Engineering and Food \\ Science, Zhejiang University, Hangzhou 310058, China \\ 5 New Countryside Development Institute, Zhejiang University, Hangzhou 310058, China \\ * Correspondence: ruanyj@zju.edu.cn
}

Received: 15 August 2018; Accepted: 20 September 2018; Published: 21 September 2018

\begin{abstract}
An aerobic denitrifier was isolated from a long-term poly (3-hydroxybutyrate-co-3hydroxyvalerate) PHBV-supported denitrification reactor that operated under alternate aerobic/anoxic conditions. The strain was identified as Marinobacter hydrocarbonoclasticus RAD-2 based on 16S rRNA-sequence phylogenetic analysis. Morphology was observed by scanning electron microscopy (SEM), and phylogenetic characteristics were analyzed with the API 20NE test. Strain RAD-2 showed efficient aerobic denitrification ability when using $\mathrm{NO}_{3}{ }^{-}-\mathrm{N}$ or $\mathrm{NO}_{2}{ }^{-}-\mathrm{N}$ as its only nitrogen source, while heterotrophic nitrification was not detected. The average $\mathrm{NO}_{3}{ }^{-}-\mathrm{N}$ and $\mathrm{NO}_{2}{ }^{-}-\mathrm{N}$ removal rates were $6.47 \mathrm{mg} /(\mathrm{L} \cdot \mathrm{h})$ and $6.32 \mathrm{mg} /(\mathrm{L} \cdot \mathrm{h})$, respectively. Single-factor experiments indicated that a 5:10 C/N ratio, $25-40{ }^{\circ} \mathrm{C}$ temperature, and 100-150 rpm rotation speed were the optimal conditions for aerobic denitrification. Furthermore, the denitrifying gene nap $A$ had the highest expression on a transcriptional level, followed by the denitrifying genes nirS and nosZ. The nor $B$ gene was found to have significantly low expression during the experiment. Overall, great aerobic denitrification ability makes the RAD-2 strain a potential alternative in enhancing nitrate management for marine recirculating aquaculture system (RAS) practices.
\end{abstract}

Keywords: aerobic denitrification; Marinobacter hydrocarbonoclasticus RAD-2; nitrogen removal; denitrifying gene expression; wastewater treatment

\section{Introduction}

Recirculating aquaculture systems (RAS) are a potential alternative to traditional aquaculture systems due to their intensive production and environmental sustainability [1]. In practice, RAS mainly use biological filters to oxidize ammonium to nitrate through nitrification, with nitrite as the intermediate product since ammonium and nitrite have direct toxicity to most fish species [2]. Nitrate concentration accumulates and reaches high concentrations during intensive fish farming. Therefore, nitrate management is very important due to its explicit long-term stress effect on cultured species [3], as well as its contribution to environmental eutrophication [4,5]. In various nitrate-removal 
methods, biological heterotrophic denitrification was proved to be an efficient approach in wastewater treatment [6]. However, the heterotrophic denitrification process depends highly on sufficient organic substances as electron donors, which inhibit its application under the circumstances of a low $\mathrm{C} / \mathrm{N}$ ratio, such as groundwater or RAS effluent treatment [4,7]. Therefore, an interesting alternative that uses biodegradable polymers as simultaneous biofilm carriers and carbon sources was proposed and demonstrated as feasible for nitrate removal in many solid-phase denitrification reactors [6-12].

Denitrification based on biodegradable polymers is usually operated under anoxic conditions due to the fact that conventional denitrification processes relied on the activities of four fundamental enzymes, that is, respiratory nitrate reductase, nitrite reductase, nitric oxide reductase, and nitrous oxide reductase, to sequentially transform nitrate into $\mathrm{N}_{2}$ [13]. Meanwhile, the first step that transfers nitrate to nitrite, encoded by the Nar gene, was found mostly sensitive to the presence of oxygen [14]. However, this anoxic solid-phase denitrification process also has byproducts due to potential electron-donor competition with other substances in practice. In our previous study, sulfate reduction to toxic sulfide was detected in marine-wastewater treatment, as sulfates are the next best terminal electron acceptor when nitrate is consumed [10]. In addition, high levels of sulfide and salinity might support dissimilatory nitrate reduction to ammonium (DNRA) over denitrification [15], which were also widely detected in other anoxic biodegradable-polymer denitrification systems $[10,12,16,17]$.

To overcome these problems, the solution of applying oxygen to cut off the route of electron transport through DNRA and sulfate reduction under alternant aerobic/anoxic conditions was demonstrated as feasible in our previous study [18]. However, the introduction of oxygen as selective pressure could lead to a more complicated microbial ecology structure [19] due to existing anoxic microzones developed by the gradual degradation of polymer carriers. In addition, many aerobic denitrifiers were reported to have the capacity for nitrate removal under aerobic conditions $[20,21]$. In the aerobic denitrification process, another electron-transfer pathway was found to be insensitive to oxygen, which relies on the expression of the nap $A$ gene (encoding periplasmic nitrate reductase) to make these groups respire nitrate and oxygen simultaneously $[22,23]$. Until now, many aerobic denitrification bacterial species have been reported, including Thiosphaera pantotropha [24], Marinobacter NNA5 and F6 [20,25], Zobellella taiwanensis DN-7 [26], and Paracoccus versutus LYM [27].

However, the above-mentioned solution might cause more complicated ecological-niche competition. Hence an opium microbial community is crucial to denitrification potential. Therefore, to enhance nitrate-removal performance in such a solid-phase denitrification system, one potential alternative could be optimizing the microbial community through bioaugmentation. For example, adding the Diaphorobacter polyhydroxybutyrativorans strain SL-205 to a solid-phase denitrification reactor could increase nitrate-removal efficiency [28]. The SL-205 strain was isolated from an anoxic poly (3-hydroxybutyrate-co-3-hydroxyvalerate) PHBV-supported denitrification reactor [29]. However, few studies have been conducted on isolating strains from an alternant aerobic/anoxic biodegradable-polymer denitrification reactor.

In this study, a strain, Marinobacter hydrocarbonoclasticus RAD-2, was isolated from a long-term PHBV-supported denitrification reactor that operated under alternate aerobic/anoxic conditions for marine RAS-effluent treatment. PCR (polymerase chain reaction) amplification of the 16S rRNA gene was performed to identify the isolated strain. In addition, evaluation of its denitrification-potential performance was carried out. Moreover, key denitrifying gene (napA, nirS, norB, and nosZ) expression was investigated to illuminate the mechanism of nitrate-removal pathways in the aerobic denitrification process. Overall, our results might provide new microbial resources and potential alternatives for enhancing nitrate-removal performance in marine RAS practices.

\section{Materials and Methods}

\subsection{Culture Media}

The denitrification medium (DM) was prepared to investigate the aerobic denitrification ability of strain RAD-2 by dissolving $2.0 \mathrm{~g}$ sodium acetate, $2.0 \mathrm{~g} \mathrm{KNO}$ (or $\mathrm{NaNO}_{2}$ ), $0.2 \mathrm{~g}$ of $\mathrm{MgSO}_{4} \cdot 7 \mathrm{H}_{2} \mathrm{O}$, 
$1.0 \mathrm{~g}$ of $\mathrm{K}_{2} \mathrm{HPO}_{4}$, and $10 \mathrm{~mL}$ of a trace-element solution in $1 \mathrm{~L}$ of distilled water. The heterotrophic nitrification medium (HNM) was prepared by dissolving $2.0 \mathrm{~g}$ sodium acetate, $0.3 \mathrm{~g}$ of $\mathrm{NH}_{4} \mathrm{Cl}, 0.2 \mathrm{~g}$ of $\mathrm{MgSO}_{4} \cdot 7 \mathrm{H}_{2} \mathrm{O}, 6.7 \mathrm{~g}$ of $\mathrm{Na}_{2} \mathrm{HPO}_{4}, 1.0 \mathrm{~g}$ of $\mathrm{KH}_{2} \mathrm{PO}_{4}$, and $10 \mathrm{~mL}$ of a trace-element solution in $1 \mathrm{~L}$ of distilled water. The composition of the trace-element solution was $50.0 \mathrm{~g}$ of EDTA, $2.2 \mathrm{~g}$ of $\mathrm{ZnSO}_{4}$, $5.5 \mathrm{~g}$ of $\mathrm{CaCl}_{2}, 5.06 \mathrm{~g}$ of $\mathrm{MnCl}_{2} \cdot 4 \mathrm{H}_{2} \mathrm{O}, 5.0 \mathrm{~g}$ of $\mathrm{FeSO}_{4} \cdot 7 \mathrm{H}_{2} \mathrm{O}, 1.1 \mathrm{~g}$ of $\left(\mathrm{NH}_{4}\right)_{6} \mathrm{Mo}_{7} \mathrm{O}_{2} \cdot 4 \mathrm{H}_{2} \mathrm{O}, 1.57 \mathrm{~g}$ of $\mathrm{CuSO}_{4} \cdot 5 \mathrm{H}_{2} \mathrm{O}$, and $1.61 \mathrm{~g}$ of $\mathrm{CoCl}_{2} \cdot 6 \mathrm{H}_{2} \mathrm{O}$ in $1 \mathrm{~L}$ of distilled water. The Luria-Bertani (LB) medium was prepared by dissolving $5.0 \mathrm{~g}$ yeast extract, $10.0 \mathrm{~g}$ peptone, and $25.0 \mathrm{~g} \mathrm{NaCl}$ in $1 \mathrm{~L}$ of distilled water and $1.5 \%(w / v)$ agar. The initial $\mathrm{pH}$ of all media was set to 7.2 , and all media were autoclaved for $20 \mathrm{~min}$ at $121{ }^{\circ} \mathrm{C}$.

\subsection{Bacteria Isolation, Screening, and Identification}

Strain RAD-2 was isolated from the biofilms of a long-term aerobic/anoxic denitrifying reactor using PHBV as simultaneous carbon source and carrier. The reactor setup and operation conditions were according to our previous study [18]. The reactor was placed in a dark artificial-climate room to retain the temperature at $26 \pm 2{ }^{\circ} \mathrm{C}$. The influent $\mathrm{NO}_{3}{ }^{-}-\mathrm{N}$ concentration was set at $70 \mathrm{mg} / \mathrm{L}$ and HRT (hydraulic retention time) was $4 \mathrm{~h}$. In detail, $20 \mathrm{~g}$ of matured PHBV samples and $10 \mathrm{~mL}$ solution samples were aseptically transferred to a flask with $100 \mathrm{~mL}$ sterile water and 10 small glass balls. To suspend the biofilms attached to the PHBV granules, the flask was shaken on a rotary shaker at $200 \mathrm{rpm}$ for $30 \mathrm{~min}$. The homogenized suspensions were serially diluted and plated using a DM, and then incubated at $28^{\circ} \mathrm{C}$ for $72 \mathrm{~h}$. A single colony with a white circle was purified by streaking onto an LB medium plate, which was then incubated for three days at $28^{\circ} \mathrm{C}$. Several colonies were obtained after strict investigation of their purity. Among the isolates, a colony that was white, irregular circle-shaped with opaque, wet, and smooth surfaces, 1-2 mm in diameter was distinguished as RAD-2. The purified isolate was stored in a $30 \%$ glycerol solution at $-80^{\circ} \mathrm{C}$.

The genomic DNA of the RAD-2 strain was isolated using a DNA extraction kit (TaKaRa Biotechnology Co. Ltd, Beijing, China). The $16 \mathrm{~S}$ rRNA gene was PCR-amplified using bacterial universal primers F27 (5'-AGAGTTTGATCMTGGCTCAG-3') and R1492 (5'-TTGGYTCCTTGT TACGACT- $\left.3^{\prime}\right)$, under the following conditions: $2 \mathrm{~min}$ at $95^{\circ} \mathrm{C}, 25$ cycles of $20 \mathrm{~s}$ at $95{ }^{\circ} \mathrm{C}, 20 \mathrm{~s}$ at $55{ }^{\circ} \mathrm{C}, 30 \mathrm{~s}$ at $72{ }^{\circ} \mathrm{C}$, and a final step of $10 \mathrm{~min}$ at $72{ }^{\circ} \mathrm{C}$. PCR products were detected on $1 \%$ agarose gel electrophoresis and ethidium bromide staining. The amplified products were purified and sequenced by the Zhejiang Institute of Microbiology (Hangzhou, Zhejiang, China). The sequence was submitted to the NCBI database (accession numbers MH725589) and compared with other available 16S rRNA gene sequences in Genbank by BLAST (http://blast.ncbi.nlm.nih.gov/Blast.cgi). A phylogenetic tree was constructed using Molecular Evolutionary Genetics Analysis software (MEGA) version X by the neighbor-joining method with 1000 bootstrap replicates.

\subsection{Nitrogen-Removal Performance Evaluation}

To evaluate aerobic denitrification capacity, a sole nitrogen source of $\mathrm{NO}_{3}{ }^{-}-\mathrm{N}$ (around $300 \mathrm{mg} / \mathrm{L}$ ) or $\mathrm{NO}_{2}{ }^{-}-\mathrm{N}$ (around $300 \mathrm{mg} / \mathrm{L}$ ) was tested in $\mathrm{DM}$ containing $\mathrm{KNO}_{3}$ or $\mathrm{NaNO}_{2}$, respectively. Afterward, a $3 \mathrm{~mL}$ seed suspension was inoculated in $250 \mathrm{~mL}$ Erlenmeyer flasks and cultured for $48 \mathrm{~h}$ with aeration at $27^{\circ} \mathrm{C}$ and $150 \mathrm{rpm}$. To evaluate the capacity for heterotrophic nitrification, a similar operation was carried out that only replaced the $\mathrm{HNM}$ with a sole nitrogen source of $\mathrm{NH}_{4} \mathrm{Cl}$ (around TAN $90 \mathrm{mg} / \mathrm{L}$ ). Cell-growth and inorganic-nitrogen changes were measured every $4 \mathrm{~h}$. The nitrogen-removal rate was calculated as below:

$$
\mathrm{R}_{\mathrm{N}}=\left(\mathrm{C}_{\mathrm{I}}-\mathrm{C}_{\mathrm{F}}\right) \times \mathrm{V} \times 4 / 1000 / \mathrm{T}
$$

where $\mathrm{R}_{\mathrm{N}}=$ nitrogen removal rate, $\mathrm{mg} /(\mathrm{L} \cdot \mathrm{h}) ; \mathrm{C}_{\mathrm{I}}=$ initial $\mathrm{NO}_{3}{ }^{-}-\mathrm{N}$ or $\mathrm{NO}_{2}{ }^{-}-\mathrm{N}$ concentration, $\mathrm{mg} / \mathrm{L}$; $\mathrm{C}_{\mathrm{F}}=$ final $\mathrm{NO}_{3}{ }^{-}-\mathrm{N}$ or $\mathrm{NO}_{2}{ }^{-}-\mathrm{N}$ concentration, $\mathrm{mg} / \mathrm{L} ; \mathrm{V}=$ volume, $\mathrm{mL} ; \mathrm{T}=$ incubated time, $\mathrm{h}$.

Single-factor experiments were also carried out to evaluate the effect of various conditions on the aerobic denitrification performance of strain RAD-2. The operation conditions for DM were as 
follows: $\mathrm{NO}_{3}{ }^{-}-\mathrm{N}$ concentration of around $300 \mathrm{mg} / \mathrm{L}, \mathrm{C} / \mathrm{N}$ ratio $10, \mathrm{NaCl} 25 \%$, temperature $25{ }^{\circ} \mathrm{C}$, rotation $150 \mathrm{rpm}$, and $1.2 \%$ inoculation $(v / v)$. For temperature experiments, the temperature was set to $5^{\circ} \mathrm{C}, 10{ }^{\circ} \mathrm{C}, 15^{\circ} \mathrm{C}, 25^{\circ} \mathrm{C}$, and $40^{\circ} \mathrm{C}$. For $\mathrm{C} / \mathrm{N}$ ratio experiments, the $\mathrm{C} / \mathrm{N}$ ratios were set to 2 , 5, 10, 15, and 20. For dissolved oxygen (DO) experiments, the rotations were set to 0, 50, 100, 150, and $200 \mathrm{rpm}$. Cell growth and indexes (nitrate, nitrite, DOC, and $\mathrm{pH}$ ) were measured during the experimental period. All tests were conducted in triplicate and none-seeded samples were used as blank control.

\subsection{RT-qPCR Analysis}

To quantitatively analyze the potential aerobic denitrification pathways of strain RAD-2, real-time PCR was conducted to amplify the denitrifying genes napA, nirS, norB, nosZ, and 16S rRNA (housekeeping gene) with RNA samples in $48 \mathrm{~h}$ experiments. Total RNA extraction and cDNA synthesis were performed by using an RNAprep Bacteria Kit and FastQuant RT Kit (Tian Gen Biotech Co. Ltd, Beijing, China), respectively. Primers are listed in Table S1. PCR amplification was performed with the following protocol: an initial denaturation step of $10 \mathrm{~min}$ at $95{ }^{\circ} \mathrm{C}$, followed by 40 cycles of denaturation at $95^{\circ} \mathrm{C}$ for $10 \mathrm{~s}$, annealing at $60{ }^{\circ} \mathrm{C}$ (napA, nirS, and nosZ) or $56^{\circ} \mathrm{C}(16 \mathrm{~S} \mathrm{~V} 3$ region and nor $B$ ) for $30 \mathrm{~s}$, and a final extension at $72{ }^{\circ} \mathrm{C}$ for $30 \mathrm{~s}$ [30]. All quantitative amplifications were conducted in triplicate using the SYBR Green Real-Time PCR Kit (Novland, Shanghai, China) and respective primers on an Mx3000P qPCR System (Agilent Technologies Co. Ltd., Beijing, China) [19].

\subsection{Analytical Methods}

The solution samples were collected and filtered through a $0.45 \mu \mathrm{m}$ filter membrane before water-quality analysis. TAN, $\mathrm{NO}_{2}{ }^{-}-\mathrm{N}$, and $\mathrm{NO}_{3}{ }^{-}-\mathrm{N}$ concentrations were analyzed according to standard methods [31]. Cell growth $\left(\mathrm{OD}_{600}\right)$ was measured by using a spectrophotometer at $600 \mathrm{~nm}$. DOC was measured using a TOC analyzer (Multi N/C 2100, Analytik Jena, Jena, Germany). DO was measured using a DO meter (SG9-FK2, Mettler Toledo, Zurich, Switzerland). Morphological analysis was performed by scanning electron microscopy (SEM) (SU8010; HITACHI, Tokyo, Japan). Fresh colonies grown on LB agar for 2 days were fixed in 1\% glutaraldehyde (prepared in cacodylate buffer, pH 7.4) at $4{ }^{\circ} \mathrm{C}$ overnight, and then completely dehydrated in ethanol. Cells were coated with gold-palladium and observed with a HITACHI 8010 scanning electron microscope (HITACHI, Tokyo, Japan). Physiological and biochemical characteristics were tested using API 20NE kits (BioMérieux Shanghai Co. Limited, Shanghai, China). API 20NE test strips was checked after incubation for $24 \mathrm{~h}$ [29].

\section{Results}

\subsection{Characteristics and Identification}

In this study, more than six pure isolates were obtained from solid DM and tested for aerobic denitrification performance by monitoring changes in nitrite and nitrate concentration in the liquid DM. A particular isolate, namely, RAD-2, exhibited the highest efficiency in nitrate and nitrite removal and was subject to further investigation. Strain RAD-2 was slightly halophilic and able to grow under aerobic conditions. The colonies of RAD-2 were yellow, small, circular in shape, semitransparent, slabby, and presented a wet surface on the LB medium. The cells were Gram-negative, bacilliform, with a size of 0.3-0.4 $\mu \mathrm{m}$ in diameter and 1.0-2.0 $\mu \mathrm{m}$ in length (Figure S1).

According to API 20 NE tests (Table 1), strain RAD-2 was positive for oxidase, and nitrate was reduced, but it was negative for arginine dihydrolase, urease, $\beta$-glucosidase, protease, and $\beta$-galactosidase. It could not perform assimilation of arabinose, mannose, mannitol, $\mathrm{N}$-acetyl-glucosamine, maltose, capric acid, adipic acid, malic acid, citric acid, and phenylacetic acid.

Analysis of 16S rRNA gene sequencing showed that strain RAD-2 belongs to the species Marinobacter hydrocarbonoclasticus, having 98\% similarity with Marinobacter hydrocarbonoclasticus strain 
ATCC 49840 and Marinobacter hydrocarbonoclasticus strain VT8. Phylogenetic analyses of the 16S rRNA gene sequencing showed that strain RAD-2 formed a distinct clade with strain ATCC 49840 and strain VT8, and this clade clustered with the nearest clade containing Marinobacter sp. NN5, Marinobacter sp. U1369-101122-SW163, and Marinobacter hydrocarbonoclasticus strain NY-4 (Figure 1). The phylogenetic position of this strain indicated that it presented a subspecies of the species Marinobacter hydrocarbonoclasticus.

Table 1. Characteristics of strain RAD-2 determined by API 20 NE tests.

\begin{tabular}{cc}
\hline API 20 NE Results & Strain RAD-2 \\
\hline Oxidase test & + \\
Nitrate reduction & + \\
Arginine dihydrolase & - \\
Urease & - \\
$\beta$-glucosidase & - \\
Protease & - \\
$\beta$-galactosidase & - \\
Assimilation of Glucose & + \\
Arabinose & - \\
Mannose & - \\
Mannitol & - \\
N-acetyl-glucosamine & - \\
Maltose & - \\
Gluconate & + \\
Capric acid & - \\
Adipic acid & - \\
Malic acid & - \\
Citric acid & - \\
Phenylacetic acid & - \\
\hline
\end{tabular}

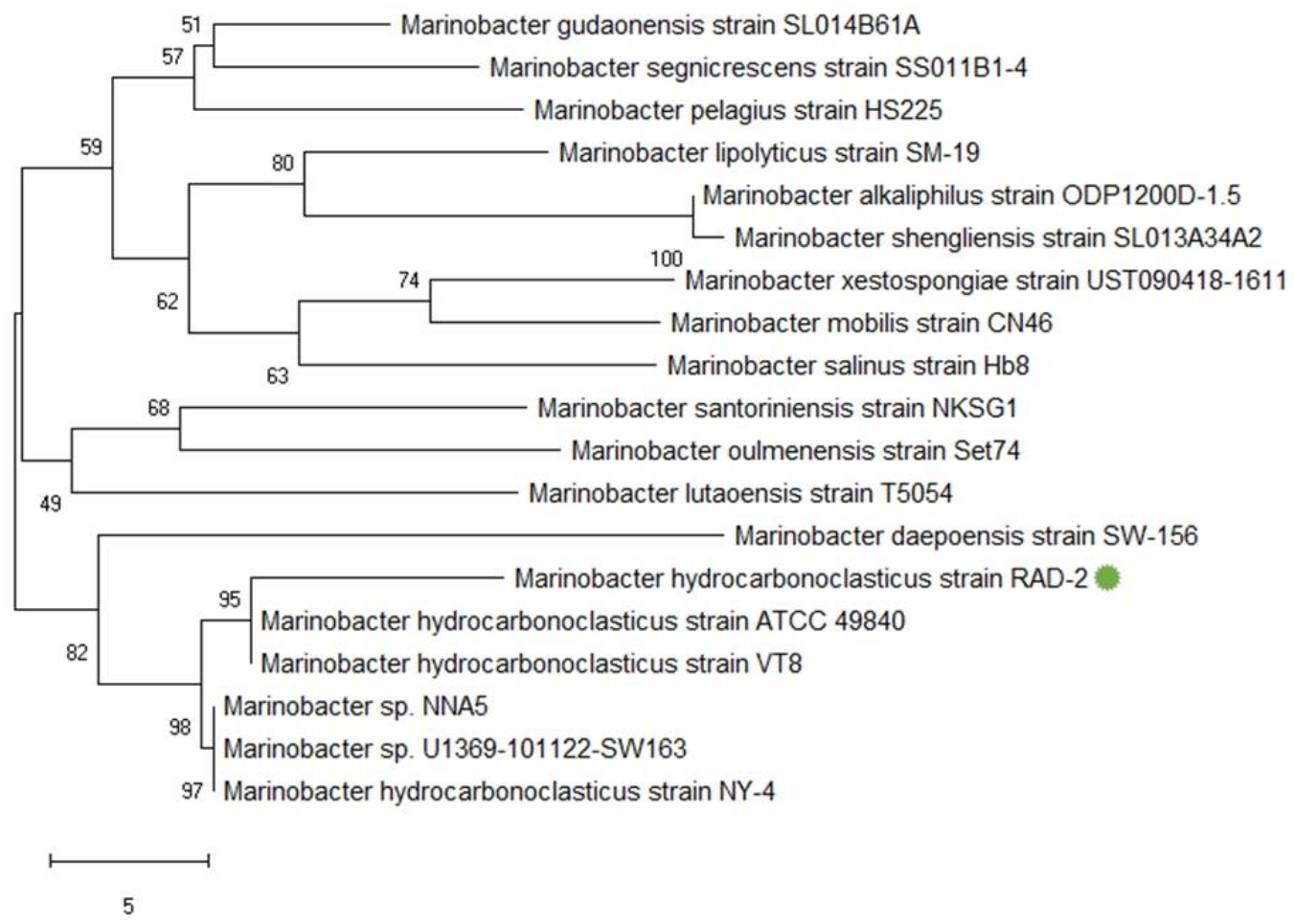

Figure 1. Neighbor-joining phylogenetic tree based on $16 \mathrm{~S}$ rRNA gene sequences showing the position of strain RAD-2 and closely related strains. Bootstrap values based on 1000 replicates are shown at branch nodes. 


\subsection{Nitrogen Removal Performance Evaluation}

\subsubsection{Aerobic Nitrogen-Removal Ability of Strain RAD-2}

The aerobic denitrification ability of strain RAD-2 under varied nitrogen sources is shown in Figure 2. After $48 \mathrm{~h}$ of incubation, $\mathrm{NO}_{3}{ }^{-}-\mathrm{N}$ concentration decreased from the initial $310.94 \mathrm{mg} / \mathrm{L}$ to the final $5.17 \mathrm{mg} / \mathrm{L}$, which indicated $98.34 \%$ removal efficiency (Panel A). The obvious lag phase was observed between 0 and $24 \mathrm{~h}$, while the logarithmic growth phase was observed between 24 and $36 \mathrm{~h}$. Nitrite accumulation occurred between 20 and $36 \mathrm{~h}$, while peak concentration of $5.05 \mathrm{mg} / \mathrm{L}$ was observed at $32 \mathrm{~h}$. In addition, a slight ammonium concentration of $2.96 \mathrm{mg} / \mathrm{L}$ was also found in the final concentration. The biomass growth of $\mathrm{OD}_{600}$ reached 1.34. Additionally, when nitrite was used as the sole nitrogen source (Panel B), $\mathrm{NO}_{2}{ }^{-}-\mathrm{N}$ concentration also decreased from $303.69 \mathrm{mg} / \mathrm{L}$ to $0.52 \mathrm{mg} / \mathrm{L}$, which was $99.83 \%$ removal efficiency. However, the backward lag phase was found in $0-44 \mathrm{~h}$, with a final biomass of 0.71 , which indicated that strain RAD-2 might be more adaptable under a nitrate condition. However, the removal rates of $6.47 \mathrm{mg} /(\mathrm{L} \cdot \mathrm{h})$ and $6.32 \mathrm{mg} /(\mathrm{L} \cdot \mathrm{h})$ were detected for strain RAD-2 when nitrate or nitrite was used as the sole nitrogen source, respectively. It should be noted that the maximum nitrite-removal rate of strain RAD-2 that could be achieved was $56.20 \mathrm{mg} /(\mathrm{L} \cdot \mathrm{h})$ at $44-48 \mathrm{~h}$ of the logarithmic growth phase (Panel B).
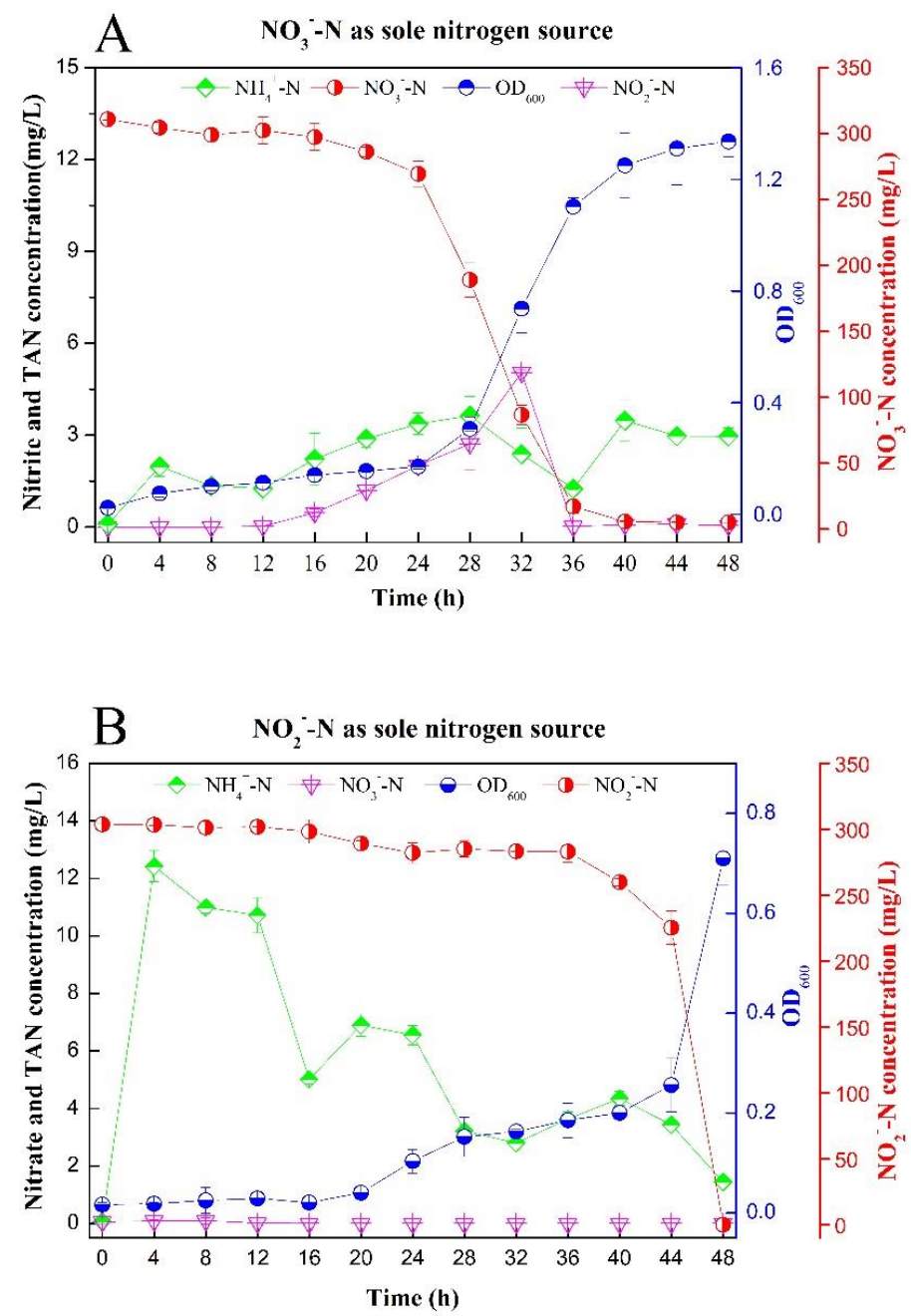

Figure 2. Aerobic nitrogen-removal characteristics and cell growth of strain RAD-2 in denitrification media (DM). (A) Nitrate as the sole nitrogen source; and (B) nitrite as the sole nitrogen source. Data shown are mean $\pm \mathrm{SD}$ (error bars) from three replicates. 
The heterotrophic nitrification performance of the strain RAD-2 is illustrated in Figure 3. After $48 \mathrm{~h}$ of incubation, TAN concentration decreased slightly from the initial $89.64 \mathrm{mg} / \mathrm{L}$ to the final $80.73 \mathrm{mg} / \mathrm{L}$, which indicated only $9.94 \%$ removal efficiency. No nitrite accumulation was found at any period, while around $0.70 \mathrm{mg} / \mathrm{L}$ nitrate was produced. Biomass built up to 0.16 after incubation, which indicated poor growth performance. Therefore, the strain RAD-2 was found to have no heterotrophic nitrification ability under current conditions.

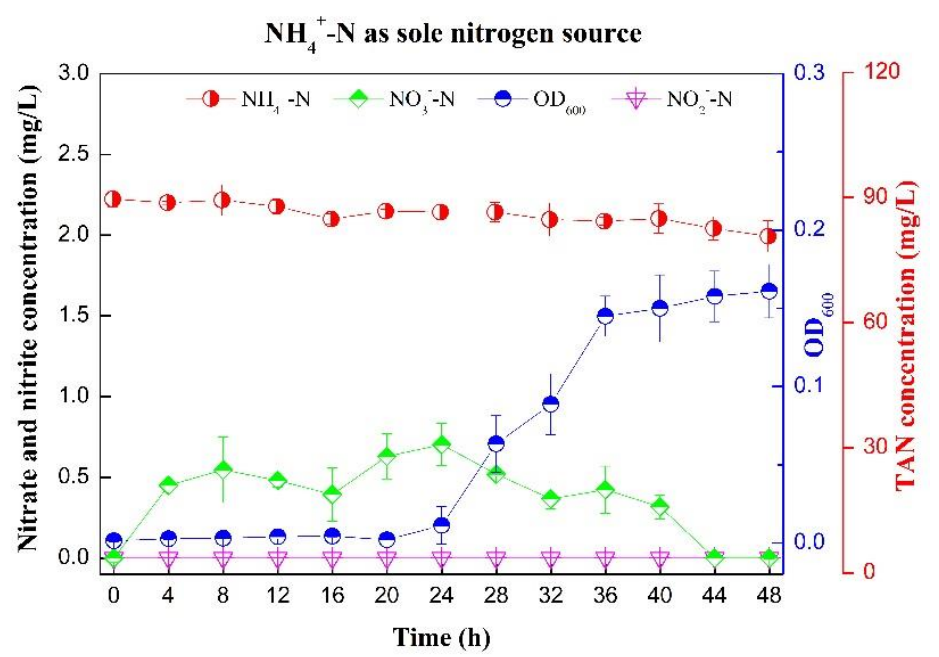

Figure 3. Aerobic ammonium-removal characteristics and cell growth of strain RAD-2 in heterotrophic nitrification media (HNM). Data shown are mean \pm SD (error bars) from three replicates.

\subsubsection{Single-Factor Experiments of Strain RAD-2}

The effects of several environmental factors on the aerobic denitrification performance of strain RAD-2 are shown in Table 2. Aerobic denitrification efficiency relied on the amount of the carbon source, which served as electron donor and energy source. In this study, C/N ratio 5:10 was found optimal for strain RAD-2, having more than 95\% nitrate-removal efficiency. A low $\mathrm{C} / \mathrm{N}$ ratio of 2 lowered nitrate-removal efficiency to $33.59 \%$ and had inadequate cell growth, with a final OD $_{600}$ of 0.32 after $48 \mathrm{~h}$ incubation. It should be noted that excess $\mathrm{C} / \mathrm{N}$ ratio also led to a decrease in denitrification performance. On a $\mathrm{C} / \mathrm{N}$ ratio of 20 , only $29.80 \%$ nitrate-removal efficiency was achieved, with a final cell growth value of 0.42 .

In general, denitrification performance is typically sensitive to temperature variations due to the differences in bacteria species. In this study, strain RAD-2 presents a mesophilic characteristic in the aerobic denitrification process. When the temperature range was $2-15{ }^{\circ} \mathrm{C}$, notably low nitrate-removal efficiency of less than $10 \%$ was obtained. Increased temperature could significantly improve denitrification performance, as near as 100\% nitrate-removal efficiency, which was gained in the $25-40{ }^{\circ} \mathrm{C}$ range.

The different rotation speeds that presented the DO effects on denitrification efficiency were also tested. In this study, strain RAD-2 gained ideal nitrate-removal efficiency in rotation speeds of 100 and 150, which is the equivalent of DO centration at 5.55 and $6.23 \mathrm{mg} / \mathrm{L}$, respectively. Otherwise, only $54.41 \%$ nitrate-removal efficiency was obtained under no rotations (DO $0.82 \mathrm{mg} / \mathrm{L}$ ). In addition, $200 \mathrm{rpm}$ (DO $7.2 \mathrm{mg} / \mathrm{L}$ ) slightly decreased nitrate-removal efficiency to $89.90 \%$. 
Table 2. Effects of varied single factors on the aerobic denitrification performance of strain RAD-2 after $48 \mathrm{~h}$ of incubation.

\begin{tabular}{cccccc}
\hline Factor & Variations & $\begin{array}{c}\text { Growth } \\
\text { (OD600) }\end{array}$ & $\begin{array}{c}\text { Initial Nitrate } \\
\text { Concentration } \\
(\mathbf{m g} / \mathbf{L})\end{array}$ & $\begin{array}{c}\text { Final Nitrate } \\
\text { Concentration } \\
(\mathbf{m g} / \mathbf{L})\end{array}$ & $\begin{array}{c}\text { Removal } \\
\text { Efficiency (\%) }\end{array}$ \\
\hline & 2 & $0.32 \pm 0.03$ & $306.33 \pm 0.95$ & $203.44 \pm 13.05$ & $33.59 \pm 4.17$ \\
C/N Ratio & 5 & $0.79 \pm 0.13$ & $305.25 \pm 0.65$ & $4.06 \pm 0.58$ & $98.67 \pm 0.19$ \\
& 10 & $1.34 \pm 0.05$ & $305.21 \pm 0.31$ & $6.48 \pm 1.93$ & $97.88 \pm 0.63$ \\
& 15 & $0.94 \pm 0.18$ & $304.02 \pm 0.26$ & $40.72 \pm 5.77$ & $86.61 \pm 1.90$ \\
& 20 & $0.42 \pm 0.05$ & $304.67 \pm 0.45$ & $213.90 \pm 12.26$ & $29.80 \pm 3.92$ \\
\hline Temperature & 5 & $0.012 \pm 0.06$ & $306.37 \pm 0.36$ & $305.74 \pm 0.40$ & $0.21 \pm 0.25$ \\
$\left({ }^{\circ} \mathrm{C}\right)$ & 10 & $0.11 \pm 0.03$ & $305.38 \pm 0.35$ & $298.75 \pm 2.59$ & $2.17 \pm 0.85$ \\
& 15 & $0.24 \pm 0.06$ & $304.01 \pm 0.38$ & $274.22 \pm 6.48$ & $9.79 \pm 2.25$ \\
& 25 & $1.12 \pm 0.12$ & $303.29 \pm 0.17$ & $6.23 \pm 3.61$ & $97.95 \pm 1.19$ \\
Rotation Speed & 40 & $1.02 \pm 0.19$ & $304.52 \pm 0.37$ & $10.18 \pm 1.18$ & $96.66 \pm 0.39$ \\
\hline (rpm) & 0 & $0.52 \pm 0.11$ & $304.86 \pm 0.50$ & $138.99 \pm 17.06$ & $54.41 \pm 5.53$ \\
& 50 & $0.67 \pm 0.05$ & $303.62 \pm 0.30$ & $92.14 \pm 11.05$ & $69.65 \pm 3.61$ \\
& 100 & $0.95 \pm 0.13$ & $305.34 \pm 0.21$ & $24.38 \pm 6.33$ & $92.02 \pm 2.08$ \\
& 150 & $1.25 \pm 0.11$ & $305.38 \pm 0.24$ & $7.02 \pm 1.51$ & $97.70 \pm 0.49$ \\
& 200 & $1.03 \pm 0.07$ & $304.43 \pm 0.27$ & $30.45 \pm 8.37$ & $89.90 \pm 2.75$ \\
\hline
\end{tabular}

\subsection{Expression of Denitrifying Genes by RT-qPCR Analysis}

The expression of key denitrifying genes in the aerobic denitrification of strain RAD-2 is shown in Figure 4. On a transcriptional level, the napA gene showed the highest expression level in this study, which indicated the aerobic denitrification characteristic of strain RAD-2. The nirS and nosZ genes had similar expression intensity, which was one order of magnitude lower than that of the nap $A$ gene. Moreover, the norB gene was found to have significantly low expression during the whole period, and its intensity was negligible when compared with other genes (napA, nirS, and nosZ). All genes showed a decrease or low expression intensity during $0-24 \mathrm{~h}$. Then, notable synergetic expressions of nap $A$, nirS, and nosZ genes showed an increase in the range 24-36 h. It should be noted that though maximum expression intensity was found at $0 \mathrm{~h}$, this time point should reflect the transcriptional state of strain RAD-2 in LB media, as we obtained the samples immediately after the inoculation.

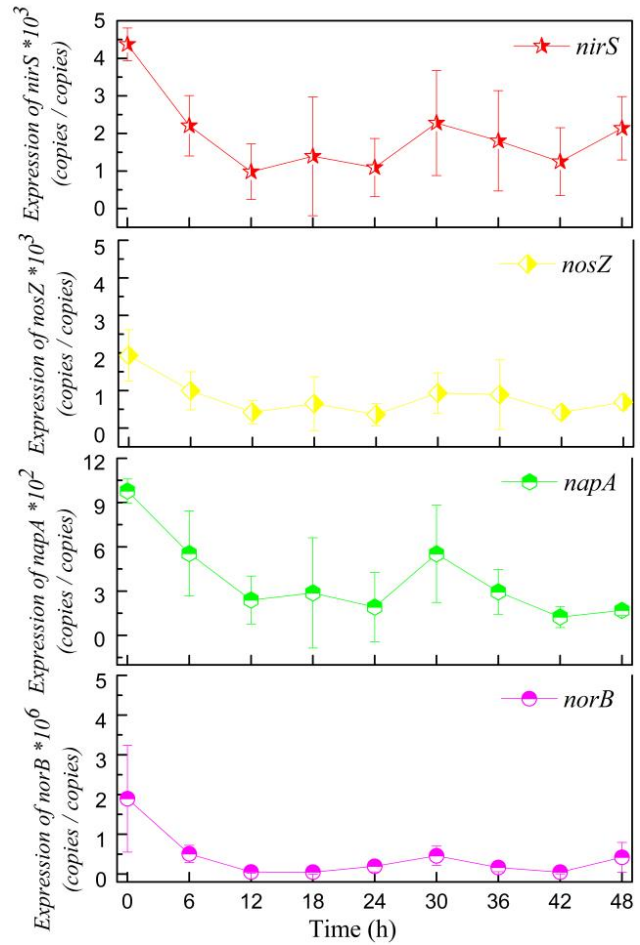

Figure 4. Aerobic denitrifying gene expression of strain RAD-2 during $48 \mathrm{~h}$ incubation. 


\section{Discussion}

\subsection{Characteristics and Identification}

In this study, Marinobacter hydrocarbonoclasticus strain RAD-2 was isolated from a denitrifying reactor using PHBV as the carbon source and biofilm carrier. In general, Marinobacter hydrocarbonoclasticus is the species of the genus Marinobacter, which belongs to the class Gammaproteobacteria. Species of this genus are Gram-staining-negative, rod-shaped, and motile [31]. A notable feature of Marinobacter hydrocarbonoclasticus is the utilization of various hydrocarbons as sole carbon and energy sources [32]. For example, using waste frying oil as the inducer carbon source, the produced biosurfactant of the strain Marinobacter hydrocarbonoclasticus SdK644 could be applied to improve crude-oil solubilization in a marine environment [33]. Therefore, strain RAD-2 might have the ability to use biodegradable polymers (PHBV etc.) for denitrification.

Based on the 16S rRNA gene sequences, strain RAD-2 formed a distinct branch with strain ATCC49840 and strain VT8, and this clade was close to the groups containing Marinobacter sp. NN5, Marinobacter sp. U1369-101122-SW163, and Marinobacter hydrocarbonoclasticus strain NY-4. However, the genus Marinobacter was reported to have many different phenotypic characteristics in the denitrification process. For example, strain RAD-2, Marinobacter sp. NN5, and Marinobacter sp. F6 were found to have efficient aerobic denitrification ability [20,25], while Marinobacter hydrocarbonoclasticus strain NY-4 only had anaerobic denitrification ability [34].

\subsection{Nitrogen-Removal Performance Evaluation}

In this study, strain RAD-2 presented efficient aerobic denitrification performance. An average removal rate of $6.47 \mathrm{mg} /(\mathrm{L} \cdot \mathrm{h})$ and $6.32 \mathrm{mg} /(\mathrm{L} \cdot \mathrm{h})$ was found in strain RAD-2 when nitrate or nitrite was used as the sole nitrogen source, respectively (Figure 2). This was much faster than several other Marinobacter strains. For example, Marinobacter sp. NN5 and Marinobacter sp. F6 were reported to have a $4.7 \mathrm{mg} /(\mathrm{L} \cdot \mathrm{h})$ and $1.46 \mathrm{mg} /(\mathrm{L} \cdot \mathrm{h}) \mathrm{NO}_{3}{ }^{-}-\mathrm{N}$ removal rate, respectively [20,25]. In other genera, Bacillus methylotrophicus $\mathrm{L} 7$ was found to have a $5.81 \mathrm{mg} /(\mathrm{L} \cdot \mathrm{h}) \mathrm{NO}_{2}{ }^{-}-\mathrm{N}$ removal rate [35]. Pseudomonas migulaer AN-1 has a $1.57 \mathrm{NO}_{3}{ }^{-}-\mathrm{N} \mathrm{mg} /(\mathrm{L} \cdot \mathrm{h})$ or $0.69 \mathrm{NO}_{2}{ }^{-}-\mathrm{N} \mathrm{mg} /(\mathrm{L} \cdot \mathrm{h})$ removal rate [36]. Pseudomonas putida Y-12 has a $1.57 \mathrm{NO}_{3}{ }^{-}-\mathrm{N} \mathrm{mg} /(\mathrm{L} \cdot \mathrm{h})$ or $1.60 \mathrm{NO}_{2}{ }^{-}-\mathrm{N} \mathrm{mg} /(\mathrm{L} \cdot \mathrm{h})$ removal rate [37]. Otherwise, strain RAD-2 cannot perform heterotrophic nitrification, which was consistent with Marinobacter sp. NN5 [20]. Only Marinobacter sp. F6 was reported to have the simultaneous ability of heterotrophic nitrification and aerobic denitrification in the Marinobacter genus [25].

Based on several single-factor experiments, strain RAD-2 showed good ecological width in marine-aquaculture conditions. A $5: 10 \mathrm{C} / \mathrm{N}$ ratio, $25-40{ }^{\circ} \mathrm{C}$ temperature, and $100-150 \mathrm{rpm}$ rotation speed were the optimal conditions for aerobic denitrification (Table 2). It is reported that Marinobacter sp. NN5 has $35{ }^{\circ} \mathrm{C}$ temperature, $6: 8 \mathrm{C} / \mathrm{N}$ ratio, and $150 \mathrm{rpm}$ rotation speed as optimal conditions [20]. Therefore, strain RAD-2 could adapt to a lower temperature of $25^{\circ} \mathrm{C}$, which might increase its application in marine aquaculture, as temperatures $25-35^{\circ} \mathrm{C}$ are the optimal environmental conditions for most cultured species. However, to better use the strain in practice, toxicology research should also be performed for strain RAD-2 in the future [38,39].

\subsection{Aerobic Denitrification Pathways Analysis}

The expression of key denitrifying genes in the aerobic denitrification of strain RAD-2 is shown in Figure 4. In general, aerobic denitrification has two different electron-transfer pathways [22]. The expression of the napA gene can guarantee that the aerobic denitrification strain still has electron-transfer capacity under aerobic conditions [22]. In anoxic denitrification, electron transfer to nitrate can be blocked as encoding gene nar $G$ is sensitive to oxygen [13]. In this study, the nap $A$ gene had a maximum expression level, which was responsible for the efficient aerobic nitrate removal performance. The synergetic expressions of the nap A, nirS, and nosZ genes increased during 24-36 h, which resulted in strain growth and nitrate elimination. (Figure 2A). It should also be noted that 
the norB gene showed very low expression (Figure 4). The norB gene was in charge of nitric oxide reductase production [22], which transfers $\mathrm{NO}$ to $\mathrm{N}_{2} \mathrm{O} . \mathrm{N}_{2} \mathrm{O}$ emission has recently been attracting more attention due to its environmental impact [40]. In the Marinobacter genus, many strains were reported as having zero $\mathrm{N}_{2} \mathrm{O}$ emissions. For example, Marinobacter sp. NN5 has total $\mathrm{N}_{2}$ production without $\mathrm{N}_{2} \mathrm{O}$ in aerobic conditions, while Marinobacter hydrocarbonoclasticus strain NY-4 was reported to produce no $\mathrm{N}_{2} \mathrm{O}$ in anaerobic conditions [20,34]. Conventionally, the high activity of nitrous oxide reductase, which was encoded by the nos $Z$ gene, was charged with the efficient transfer of $\mathrm{N}_{2} \mathrm{O}$ to $\mathrm{N}_{2}$. Here, we also give molecular evidence that the Marinobacter hydrocarbonoclasticus RAD-2 strain has little expression intensity, which might be another reason for its zero $\mathrm{N}_{2} \mathrm{O}$ emissions. Since $\mathrm{N}_{2} \mathrm{O}$ is an important greenhouse gas, and aquaculture systems are considered an important anthropogenic source of $\mathrm{N}_{2} \mathrm{O}$ emission [41], strain RAD-2 might have great potential for aerobic denitrification in marine RAS applications.

\section{Conclusions}

An aerobic denitrifier strain was isolated from a long-term PHBV-supported denitrification reactor that was operated under alternate aerobic/anoxic conditions. The strain was identified as Marinobacter hydrocarbonoclasticus RAD-2 based on $16 \mathrm{~S}$ rRNA-sequence phylogenetic analysis. Strain RAD-2 showed high efficiency for aerobic denitrification when using $\mathrm{NO}^{-}{ }^{-} \mathrm{N}$ or $\mathrm{NO}_{2}{ }^{-}-\mathrm{N}$ as the sole nitrogen source, while almost being unable to perform heterotrophic nitrification. The average $\mathrm{NO}_{3}{ }^{-}-\mathrm{N}$ and $\mathrm{NO}_{2}{ }^{-}-\mathrm{N}$ removal rates were $6.47 \mathrm{mg} /(\mathrm{L} \cdot \mathrm{h})$ and $6.32 \mathrm{mg} /(\mathrm{L} \cdot \mathrm{h})$, respectively. Single-factor experiments indicated that a $5: 10 \mathrm{C} / \mathrm{N}$ ratio, $25-40{ }^{\circ} \mathrm{C}$ temperature, and $100-150 \mathrm{rpm}$ rotation speed were the optimal conditions for aerobic denitrification. Furthermore, the denitrifying gene nap $A$ had maximum expression intensity on a transcriptional level, followed by nirS and nosZ. The nor B gene was found to have significantly low expression during the whole period. Therefore, the denitrifying pathways showed its aerobic denitrification characteristic and potentially fewer $\mathrm{N}_{2} \mathrm{O}$ emissions. Overall, the efficient aerobic denitrification performance of strain RAD-2 makes it a potential candidate for bioaugmentation to improve the effluent treatment of marine RAS.

Supplementary Materials: The following are available online at http:/ / www.mdpi.com/2073-4441/10/10/1298/ s1, Figure S1: Scanning electron microscope micrograph of Marinobacter hydrocarbonoclasticus strain RAD-2, Table S1: PCR primers used of $16 s$ rRNA, napA, nirS, norB and nosZ for strain RAD-2.

Author Contributions: Conceptualization: D.K., Y.R. and F.L.; data curation: W.L. and Y.D.; investigation: D.K., W.L., G.C. and J.Y.; writing—original draft: D.K. and Y.R.; writing—review and editing: Y.R.

Funding: This research was funded by Natural Science Fund of China grant number [31402348 and 41401556], Key Research and Development Projects of Zhejiang Province grant number [2018C02037] and Agriculture Technology Extension Funds of Zhejiang University (2017). The APC was funded by Key Research and Development Projects of Zhejiang Province [2018C02037].

Acknowledgments: We thank the reviewers for their insightful comments and suggestions.

Conflicts of Interest: The authors declare no conflict of interest.

\section{References}

1. Martins, C.I.M.; Eding, E.H.; Verdegem, M.C.J.; Heinsbroek, L.T.N.; Schneider, O.; Blancheton, J.P.; d'Orbcastel, E.R.; Verreth, J.A.J. New developments in recirculating aquaculture systems in europe: A perspective on environmental sustainability. Aquac. Eng. 2010, 43, 83-93. [CrossRef]

2. Gutierrez-Wing, M.T.; Malone, R.F. Biological filters in aquaculture: Trends and research directions for freshwater and marine applications. Aquac. Eng. 2006, 34, 163-171. [CrossRef]

3. Van Bussel, C.G.J.; Schroeder, J.P.; Wuertz, S.; Schulz, C. The chronic effect of nitrate on production performance and health status of juvenile turbot (Psetta maxima). Aquaculture 2012, 326-329, $163-167$. [CrossRef]

4. Van Rijn, J.; Tal, Y.; Schreier, H.J. Denitrification in recirculating systems: Theory and applications. Aquac. Eng. 2006, 34, 364-376. [CrossRef] 
5. Kraft, B.; Tegetmeyer, H.E.; Sharma, R.; Klotz, M.G.; Ferdelman, T.G.; Hettich, R.L.; Geelhoed, J.S.; Strous, M. The environmental controls that govern the end product of bacterial nitrate respiration. Science 2014, 345, 676-679. [CrossRef] [PubMed]

6. Wang, J.; Chu, L. Biological nitrate removal from water and wastewater by solid-phase denitrification process. Biotechnol. Adv. 2016, 34, 1103-1112. [CrossRef] [PubMed]

7. Wu, W.; Yang, L.; Wang, J. Denitrification using PBS as carbon source and biofilm support in a packed-bed bioreactor. Environ. Sci. Pollut. Res. 2013, 20, 333-339. [CrossRef] [PubMed]

8. Shen, Z.; Zhou, Y.; Wang, J. Comparison of denitrification performance and microbial diversity using starch/polylactic acid blends and ethanol as electron donor for nitrate removal. Bioresour. Technol. 2013, 131, 33-39. [CrossRef] [PubMed]

9. $\mathrm{Xu}, \mathrm{Z}$.; Chai, X. Effect of weight ratios of PHBV/PLA polymer blends on nitrate removal efficiency and microbial community during solid-phase denitrification. Int. Biodeterior. Biodegrad. 2017, 116, 175-183. [CrossRef]

10. Zhu, S.M.; Deng, Y.L.; Ruan, Y.J.; Guo, X.S.; Shi, M.M.; Shen, J.Z. Biological denitrification using poly (butylene succinate) as carbon source and biofilm carrier for recirculating aquaculture system effluent treatment. Bioresour. Technol. 2015, 192, 603-610. [CrossRef] [PubMed]

11. Qiu, T.; Liu, L.; Gao, M.; Zhang, L.; Tursun, H.; Wang, X. Effects of solid-phase denitrification on the nitrate removal and bacterial community structure in recirculating aquaculture system. Biodegradation 2016, 27, 165-178. [CrossRef] [PubMed]

12. Feng, L.; Chen, K.; Han, D.; Zhao, J.; Lu, Y.; Yang, G.; Mu, J.; Zhao, X. Comparison of nitrogen removal and microbial properties in solid-phase denitrification systems for water purification with various pretreated lignocellulosic carriers. Bioresour. Technol. 2017, 224, 236-245. [CrossRef] [PubMed]

13. Zumft, W.G. Cell biology and molecular basis of denitrification. Microbiol. Mol. Biol. Rev. 1997, 61, 533-616. [PubMed]

14. Körner, H.; Zumft, W.G. Expression of denitrification enzymes in response to the dissolved oxygen level and respiratory substrate in continuous culture of Pseudomonas stutzeri. Appl. Environ. Microbiol. 1989, 55, 1670-1676. [PubMed]

15. Giblin, A.E.; Tobias, C.R.; Song, B.; Weston, N.; Banta, G.T.; Rivera-Monroy, V.H. The importance of dissimilatory nitrate reduction to ammonium (DNRA) in the nitrogen cycle of coastal ecosystems. Oceanography 2013, 26, 124-131. [CrossRef]

16. Chu, L.; Wang, J. Denitrification performance and biofilm characteristics using biodegradable polymers PCL as carriers and carbon source. Chemosphere 2013, 91, 1310-1316. [CrossRef] [PubMed]

17. Shen, Z.; Wang, J. Biological denitrification using cross-linked starch/PCL blends as solid carbon source and biofilm carrier. Bioresour. Technol. 2011, 102, 8835-8838. [CrossRef] [PubMed]

18. Ruan, Y.J.; Deng, Y.L.; Guo, X.S.; Timmons, M.B.; Lu, H.F.; Han, Z.Y.; Ye, Z.Y.; Shi, M.M.; Zhu, S.M. Simultaneous ammonia and nitrate removal in an airlift reactor using poly (butylene succinate) as carbon source and biofilm carrier. Bioresour. Technol. 2016, 216, 1004-1013. [CrossRef] [PubMed]

19. Deng, Y.L.; Ruan, Y.J.; Zhu, S.M.; Guo, X.S.; Han, Z.Y.; Ye, Z.Y.; Liu, G.; Shi, M.M. The impact of DO and salinity on microbial community in poly (butylene succinate) denitrification reactors for recirculating aquaculture system wastewater treatment. AMB Express 2017, 7, 113. [CrossRef] [PubMed]

20. Liu, Y.; Ai, G.M.; Miao, L.L.; Liu, Z.P. Marinobacter strain NNA5, a newly isolated and highly efficient aerobic denitrifier with zero $\mathrm{N}_{2} \mathrm{O}$ emission. Bioresour. Technol. 2016, 206, 9-15. [CrossRef] [PubMed]

21. Zhang, S.; Sun, X.; Fan, Y.; Qiu, T.; Gao, M.; Wang, X. Heterotrophic nitrification and aerobic denitrification by diaphorobacter polyhydroxybutyrativorans SL-205 using poly (3-hydroxybutyrate-co-3-hydroxyvalerate) as the sole carbon source. Bioresour. Technol. 2017, 241, 500-507. [CrossRef] [PubMed]

22. Chen, J.; Strous, M. Denitrification and aerobic respiration, hybrid electron transport chains and co-evolution. Biochim. Biophys. Acta Bioenergy 2013, 1827, 136-144. [CrossRef] [PubMed]

23. Zheng, M.; He, D.; Ma, T.; Chen, Q.; Liu, S.; Ahmad, M.; Gui, M.; Ni, J. Reducing $\mathrm{NO}$ and $\mathrm{N}_{2} \mathrm{O}$ emission during aerobic denitrification by newly isolated Pseudomonas Stutzeri PCN-1. Bioresour. Technol. 2014, 162, 80-88. [CrossRef] [PubMed]

24. Robertson, L.A.; Kuenen, J.G. Aerobic denitrification: A controversy revived. Arch. Microbiol. 1984, 139, 351-354. [CrossRef] 
25. Zheng, H.Y.; Liu, Y.; Gao, X.Y.; Ai, G.M.; Miao, L.L.; Liu, Z.P. Characterization of a marine origin aerobic nitrifying-denitrifying bacterium. J. Biosci. Bioeng. 2012, 114, 33-37. [CrossRef] [PubMed]

26. Lei, Y.; Wang, Y.; Liu, H.; Xi, C.; Song, L. A novel heterotrophic nitrifying and aerobic denitrifying bacterium, Zobellella taiwanensis DN-7, can remove high-strength ammonium. Appl. Microbiol. Biotechnol. 2016, 100, 4219-4229. [CrossRef] [PubMed]

27. Shi, Z.; Zhang, Y.; Zhou, J.; Chen, M.; Wang, X. Biological removal of nitrate and ammonium under aerobic atmosphere by Paracoccus versutus LYM. Bioresour. Technol. 2013, 148, 144-148. [CrossRef] [PubMed]

28. Zhang, S.; Sun, X.; Wang, X.; Qiu, T.; Gao, M.; Sun, Y.; Cheng, S.; Zhang, Q. Bioaugmentation with Diaphorobacter polyhydroxybutyrativorans to enhance nitrate removal in a poly (3-hydroxybutyrate-co-3hydroxyvalerate)-supported denitrification reactor. Bioresour. Technol. 2018, 263, 499-507. [CrossRef] [PubMed]

29. Qiu, T.; Zuo, Z.; Gao, J.; Gao, M.; Han, M.; Sun, L.; Zhang, L.; Wang, X. Diaphorobacter polyhydroxybutyrativorans sp. Nov., a novel poly (3-hydroxybutyrate-co-3-hydroxyvalerate)-degrading bacterium isolated from biofilms. Int. J. Syst. Evol. Microbiol. 2015, 65, 2913-2918. [CrossRef] [PubMed]

30. Gui, M.; Chen, Q.; Ni, J. Effect of sulfamethoxazole on aerobic denitrification by strain Pseudomonas stutzeri PCN-1. Bioresour. Technol. 2017, 235, 325. [CrossRef] [PubMed]

31. Clesceri, L.S. Standard Methods for the Examination of Water and Wastewater, 20th ed.; American Public Health Association: Washington, DC, USA, 1998.

32. Gauthier, M.J.; Lafay, B.; Christen, R.; Fernandez, L.; Acquaviva, M.; Bonin, P.; Bertrand, J.C. Marinobacter hydrocarbonoclasticus gen. nov., sp. nov., a new, extremely halotolerant, hydrocarbon-degrading marine bacterium. Int. J. Syst. Bacteriol. 1992, 42, 568. [CrossRef] [PubMed]

33. Zenati, B.; Chebbi, A.; Badis, A.; Eddouaouda, K.; Boutoumi, H.; El Hattab, M.; Hentati, D.; Chelbi, M.; Sayadi, S.; Chamkha, M.; et al. A non-toxic microbial surfactant from Marinobacter hydrocarbonoclasticus sdk644 for crude oil solubilization enhancement. Ecotoxicol. Environ. Saf. 2018, 154, 100-107. [CrossRef] [PubMed]

34. Li, R.; Zi, X.; Wang, X.; Zhang, X.; Gao, H.; Hu, N. Marinobacter hydrocarbonoclasticus NY-4, a novel denitrifying, moderately halophilic marine bacterium. SpringerPlus 2013, 2, 346. [CrossRef] [PubMed]

35. Wan, C.; Yang, X.; Lee, D.-J.; Du, M.; Wan, F.; Chen, C. Aerobic denitrification by novel isolated strain using $\mathrm{NO}_{2}{ }^{-}-\mathrm{N}$ as nitrogen source. Bioresour. Technol. 2011, 102, 7244-7248. [CrossRef] [PubMed]

36. Qu, D.; Wang, C.; Wang, Y.; Zhou, R.; Ren, H. Heterotrophic nitrification and aerobic denitrification by a novel groundwater origin cold-adapted bacterium at low temperatures. RSC Adv. 2015, 5, 5149-5157. [CrossRef]

37. Ye, Q.; Li, K.; Li, Z.; Xu, Y.; He, T.; Tang, W.; Xiang, S. Heterotrophic nitrification-aerobic denitrification performance of strain $\mathrm{Y}-12$ under low temperature and high concentration of inorganic nitrogen conditions. Water 2017, 9, 835. [CrossRef]

38. Xin, X.; Huang, G.; Liu, X.; An, C.; Yao, Y.; Weger, H.; Zhang, P.; Chen, X. Molecular toxicity of triclosan and carbamazepine to green algae Chlorococcum sp.: A single cell view using synchrotron-based Fourier transform infrared spectromicroscopy. Environ. Pollut. 2017, 226, 12-20. [CrossRef] [PubMed]

39. Xin, X.; Huang, G.; An, C.; Huang, C.; Weger, H.; Zhao, S.; Zhou, Y.; Rosendahl, S. Insights into the Toxicity of Triclosan to Green Microalga Chlorococcum sp. Using Synchrotron-Based Fourier Transform Infrared Spectromicroscopy: Biophysiological Analyses and Roles of Environmental Factors. Environ. Sci. Technol. 2018, 52, 2295-2306. [CrossRef] [PubMed]

40. Caniani, D.; Esposito, G.; Gori, R.; Mannina, G. Towards a new decision support system for design, management and operation of wastewater treatment plants for the reduction of greenhouse gases emission. Water 2015, 7, 5599-5616. [CrossRef]

41. Hu, Z.; Lee, J.W.; Chandran, K.; Kim, S.; Khanal, S.K. Nitrous oxide $\left(\mathrm{N}_{2} \mathrm{O}\right)$ emission from aquaculture: A review. Environ. Sci. Technol. 2012, 46, 6470-6480. [CrossRef] [PubMed]

(C) 2018 by the authors. Licensee MDPI, Basel, Switzerland. This article is an open access article distributed under the terms and conditions of the Creative Commons Attribution (CC BY) license (http:// creativecommons.org/licenses/by/4.0/). 